\title{
The effect of fat-coated organic acid salts and a feed enzyme on growth performance, nutrient utilization, microflora activity, and morphology of the small intestine in broiler chickens*
}

\author{
S. Smulikowska ${ }^{1}$, J. Czerwiński, A. Mieczkowska and J. Jankowiak
}

\author{
The Kielanowski Institute of Animal Physiology and Nutrition, Polish Academy of Sciences \\ 05-110 Jabtonna, Poland
}

(Received 14 October 2008; revised version 28 April 2009; accepted 24 June 2009)

\begin{abstract}
The efficacy of two fat-coated organic acid preparations added alone or in combination with a commercial feed enzyme to a wheat- and soyabean meal-based broiler diet was investigated. Fat-coated sodium butyrate (SB) and blend G composed of fumaric acid, calcium formate, calcium propionate and potassium sorbite were used. Each preparation was added at $1 \mathrm{~g} / \mathrm{kg}$ diets cold pelleted. Two hundred 40-day-old Cobb broiler females were allocated to 6 groups, 40 in each, and fed experimental diets from the first day of life to slaughter. Histomorphometry of the jejunum and ileum was performed on eight 8-d-old chicks per group, performance was measured from day 8 to 21 of life on 16 chickens kept in individual cages per group, while the balance trial was conducted using 9 chickens per group. Measurements of digesta $\mathrm{pH}$ in the crop, stomach, jejunum and caecum were taken in 30-day-old birds. Additionally, viscosity of ileal digesta and short-chain fatty acid (SCFA) concentrations in caecal digesta were determined.

No effect of the feed additives on small intestinal morphology was found in the ileum, but in the jejunum blend $\mathrm{G}$ increased the villi height $(\mathrm{P}<0.001)$, crypt depth $(\mathrm{P}<0.01)$ and the width of the tunica muscularis $(\mathrm{P}<0.05)$. The added enzyme decreased villi width $(\mathrm{P}<0.05)$. The effect of $\mathrm{SB}$ on intestinal morphology was insignificant. The growth performance of birds fed diets supplemented with both SB and feed enzyme was increased in comparison with other experimental groups $(\mathrm{P}<0.05)$. Both preparations $\mathrm{G}$ and $\mathrm{SB}$ increased nitrogen retention, while enzyme supplementation increased organic matter digestibility and the $\mathrm{AME}_{\mathrm{N}}$ value of diets. Neither preparations $\mathrm{G}$ nor $\mathrm{SB}$
\end{abstract}

\footnotetext{
* Supported by the Polish Ministry for Scientific Research and Information Technology, Grant No. 2 P06Z 03428

${ }^{1}$ Corresponding author: e-mail: s.smulikowska@ifzz.pan.pl
} 
affected ileal digesta viscosity, but this parameter decreased by $10 \%(\mathrm{P}<0.05)$ following enzyme supplementation. The effect of additives on the $\mathrm{pH}$ of digesta was not significant, except enzyme supplementation, which decreased the $\mathrm{pH}(\mathrm{P}<0.05)$ of jejunal digesta. Neither additive affected total short-chain fatty acids concentration in caecal digesta.

KEY WORDS: organic acids, feed enzyme, digesta viscosity, intestinal morphology, SCFA, broiler chickens

\section{INTRODUCTION}

Short-chain fatty acids (SCFA) act as bioregulators and gut growth promoters in nonruminants (Mroz et al., 2006). Production of SCFA by caecal microflora of broiler chickens plays an important role in preventing colonization of the gastrointestinal tract by pathogens, including Salmonella (Corrier et al., 1995). Van der Wielen et al. (2000) found a negative correlation between the Enterobacteriaceae count and concentration of undissociated acetate, propionate and butyrate in chickens caeca. Butyrate appears to also play a role in the development of intestinal epithelium of rats, pigs (Mroz et al., 2006) and chickens (Hu and Guo, 2007). In broilers, SCFA are generated intraluminally by gut microflora from fermentable substrates, mostly from resistant starch and nonstarch polysaccharides. Supplementing broiler diets with feed enzymes decreases the amount of substrates for microbial fermentation in the ileum, but provides a fermentation source for caecal bacteria (Bedford, 2000). Bacterial counts and acetate, propionate and butyrate levels are quite low in the distal small intestine and caecum of broiler chicks in first days of life, then increase and reach a plateau by approximately $15 \mathrm{~d}$ of age (van der Wielen et al., 2000). Supplementing broiler diets with SCFA is considered a potential alternative for feed antibiotics and can also precipitate the development of intestinal epithelium. Non-protected SCFA added into poultry feed are readily digested (Bolton and Dewar, 1965; Hume et al., 1993), while different systems of microencapsulation prevent dissociation of SCFA in the stomach and help to address their bioactivity towards distal parts of the intestine and effectively modulate the intestinal microflora and mucosal morphology in weaning pigs and in chickens (Mroz et al., 2006; Hu and Guo, 2007).

The objective of the study was to determine the effects of dietary administration of two fat-coated organic acid preparations and feed enzyme on small intestinal morphology in the early phase of growth, on performance and nutrient utilization and SCFA concentration in caecal digesta of broiler chickens. 


\section{MATERIAL AND METHODS}

\section{Experimental diets}

The composition of the experimental diets is shown in Table 1. The basal diet was formulated to meet the dietary recommendations for commercial broiler chickens (Smulikowska and Rutkowski, 2005) and contained small amounts of peas, potato fibre preparation and wheat starch. Diets were free from growthpromoting antibiotics, but contained a coccidiostat (Diclazuril $1 \mathrm{mg} / \mathrm{kg}$ ). The control basal diet (B) was unsupplemented, while diet BE was supplemented with $1 \mathrm{~g} / \mathrm{kg}$ enzyme preparation (Avizyme 1500, Danisco Cultor, containing endo1, 3 (4)- $\beta$-glucanase $150 \mathrm{U} / \mathrm{g}$, endo-1,4- $\beta$-xylanase $350 \mathrm{U} / \mathrm{g}$, subtilisin $4000 \mathrm{U} / \mathrm{g}$,

Table 1. Composition of experimental diets, g/kg air-dry matter

\begin{tabular}{|c|c|c|c|c|c|c|}
\hline \multirow{2}{*}{ Item } & \multicolumn{6}{|c|}{ Dietary treatments ${ }^{1}$} \\
\hline & $\mathrm{B}$ & BG & $\mathrm{BSB}$ & $\mathrm{BE}$ & BEG & BESB \\
\hline \multicolumn{7}{|l|}{ Ingredient } \\
\hline wheat $(12.6 \% \mathrm{CP})$ & 289.1 & 289.1 & 289.1 & 289.1 & 289.1 & 289.1 \\
\hline pea $(21.1 \% \mathrm{CP})$ & 30 & 30 & 30 & 30 & 30 & 30 \\
\hline soyabean meal $(43.7 \% \mathrm{CP})$ & 364.4 & 364.4 & 364.4 & 364.4 & 364.4 & 364.4 \\
\hline maize $(9.4 \% \mathrm{CP})$ & 200 & 200 & 200 & 200 & 200 & 200 \\
\hline potato fibre & 20 & 20 & 20 & 20 & 20 & 20 \\
\hline limestone & 6 & 6 & 6 & 6 & 6 & 6 \\
\hline monocalcium phosphate & 13.5 & 13.5 & 13.5 & 13.5 & 13.5 & 13.5 \\
\hline $\mathrm{NaCl}$ & 3 & 3 & 3 & 3 & 3 & 3 \\
\hline soyabean oil & 60 & 60 & 60 & 60 & 60 & 60 \\
\hline mineral-vitamin premix ${ }^{2}$ & 10 & 10 & 10 & 10 & 10 & 10 \\
\hline L-lysine, 78\% & 1 & 1 & 1 & 1 & 1 & 1 \\
\hline DL-methionine, $98 \%$ & 1 & 1 & 1 & 1 & 1 & 1 \\
\hline wheat starch & 2 & 1 & 1 & 1 & - & - \\
\hline feed enzyme (E) & - & - & - & 1 & 1 & 1 \\
\hline organic acid blend $(\mathrm{G})$ & - & 1 & - & - & 1 & - \\
\hline sodium butyrate (SB) & - & - & 1 & - & - & 1 \\
\hline \multicolumn{7}{|l|}{ Nutrient level } \\
\hline crude protein, $\mathrm{g} / \mathrm{kg}$ (analysed) & 226 & 224 & 224 & 228 & 224 & 227 \\
\hline metabolizable energy, $\mathrm{MJ} / \mathrm{kg}^{3}$ & 12.32 & 12.32 & 12.32 & 12.32 & 12.32 & 12.32 \\
\hline \multicolumn{7}{|c|}{ 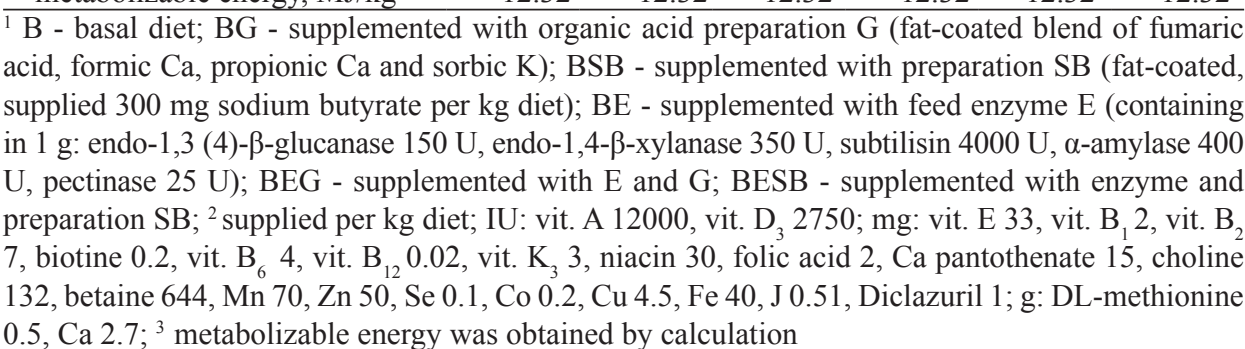 } \\
\hline
\end{tabular}


$\alpha$-amylase $400 \mathrm{U} / \mathrm{g}$ and pectinase $25 \mathrm{U} / \mathrm{g}$ according to provider). Diets BG and BEG were supplemented with $1 \mathrm{~g} / \mathrm{kg}$ organic acid preparation $(\mathrm{G})$, composed of fumaric acid, calcium formate, calcium propionate and potassium sorbite, coated with plant triglycerides (Galliacid, Vetagro). Diets BSB and BESB were supplemented with $1 \mathrm{~g} / \mathrm{kg}$ SB preparation, containing $30 \%$ sodium butyrate coated with plant triglycerides (Adimix 30, Nutri-Ad). Each supplement was substituted for $1 \mathrm{~g}$ of wheat starch. All diets were cold pelleted (the temperature of pellets coming from a die was about $60^{\circ} \mathrm{C}$, on average) on a CL-2 CPM Laboratory Pellet Mill (CA, USA). The same diets were utilized in a balance trial, but prior to pelleting $3 \mathrm{~g} \mathrm{Cr}_{2} \mathrm{O}_{3}$ per $\mathrm{kg}$ DM were added on top as a marker.

\section{Animals and care}

The Local Animal Care and Use Committee approved all procedures. Two hundred and forty 1-day-old vent sexed broiler females (Cobb 500) were obtained from a local commercial hatchery. The chicks were randomly allocated to 6 experimental treatments. For the first week of life, the birds were kept in battery cages and each treatment had 2 replicates of 20 birds. Room temperature was maintained at $30^{\circ} \mathrm{C}$ for the first 3 days and was gradually reduced according to normal management practice. A light cycle of $23 \mathrm{~h}$ light and $1 \mathrm{~h}$ darkness was maintained throughout the study. Chickens from the first day of life to slaughter were provided with the experimental diets (1-3 d mash, from $4^{\text {th }}$ day pellets) and had free access to feed and water. Daily mortalities were recorded.

On day 8 , the birds were deprived of feed for $4 \mathrm{~h}$ and weighed. Eight chickens were selected from each group, sacrificed by cervical dislocation, liver and caeca with contents were weighed and $3 \mathrm{~cm}$ long segments of the jejunum (3 $\mathrm{cm}$ anterior from Meckel's diverticulum) and $3 \mathrm{~cm}$ long segments of the ileum (5 $\mathrm{cm}$ anterior from the ileo-caecal junction) were taken for histological examination.

\section{Growth and balance trial}

Sixteen 8-d-old chickens selected from each group with a average body weight of $173 \mathrm{~g}$ were transferred to individual metabolism cages and given the respective experimental diets ad libitum. On day 22, following $4 \mathrm{~h}$ of feed deprivation, the birds were weighed and feed consumption in each cage was recorded. Body weight gain (BWG) and feed conversion ratio (FCR) were calculated.

On day 22, 9 chickens with an average body weight of $920 \mathrm{~g}$ were selected from each group and fed the respective balance diets (Table 1) containing $3 \mathrm{~g} / \mathrm{kg} \mathrm{Cr}{ }_{2} \mathrm{O}_{3}$ for 7 days. The remaining chickens were provided the respective experimental diets without a marker. Feed intake during the balance trial was measured; excreta 
were collected for the last 4 days and immediately frozen at $-18^{\circ} \mathrm{C}$.

After finishing the balance trial, all chickens received the respective diets without marker, and on the following two days they were weighed and sacrificed by cervical dislocation. The abdominal cavity was opened and the liver, caeca, spleen and bursa of Fabricious were excised and weighed. The luminal contents of the crop, stomach (proventriculus/gizzard), jejunum, anterior ileum and posterior ileum (the last $15 \mathrm{~cm}$ before ileo-caeco-colic junction) and caeca were collected, pooled by segment for every 2 chickens and sampled.

\section{Analytical procedures}

The pooled samples of crop, stomach, jejunum and caecum digesta were mixed immediately with deionized water $(1: 1 \mathrm{w} / \mathrm{w})$ and $\mathrm{pH}$ was measured by a digital pH-meter (WTW pH/340, Germany) using pH standard WTW D-82362 Weilheim (model STP4) at room temperature.

Samples of digesta from the posterior ileum were centrifuged at $10000 \mathrm{~g}$ for 10 min using a Beckman centrifuge (model $\mathrm{J} 2-21$ with $\mathrm{J}-20$ rotor) at $4^{\circ} \mathrm{C}$ and the viscosity of the supernatant $(0.5 \mathrm{ml}$ aliquot) was immediately measured with the use of a Brookfield Digital cone/plate viscometer (model LVDV II + , Brookfield Engineering Laboratories, Stoughton, MA, USA). Readings were expressed in mPas.

The digesta from the anterior ileum and caeca were sampled for DM analysis (AOAC, 1990), and then the caecal digesta was adjusted to $\mathrm{pH} 8.0$ and stored at $-20^{\circ} \mathrm{C}$ for SCFA determination. SCFA content was measured according to Ziołecki and Kwiatkowska (1973) using isocaproic acid as an internal standard on an HP 5890 AII gas chromatograph equipped with a Supelco Nukol capillary column $(30 \mathrm{~m} \times$ $0.25 \mathrm{~mm}$ internal diameter, film $0.25 \mathrm{~mm}$ ). The initial column temperature was set at $100^{\circ} \mathrm{C}$ for $2 \mathrm{~min}$, increased to $140^{\circ} \mathrm{C}$ at $10^{\circ} \mathrm{C} / \mathrm{min}$ and held at the final temperature for $20 \mathrm{~min}$.

Prior to analysis, the excreta from the balance trial were dried for $12 \mathrm{~h}$ at $60^{\circ} \mathrm{C}$, kept uncovered for $48 \mathrm{~h}$ and ground to pass a $1 \mathrm{~mm}$ sieve. The chemical composition of diets and excreta was determined according to AOAC (1990); chromic oxide was analysed spectrophotometrically following wet ashing according to Hinsberg et al. (1953). Gross energy was measured with a Parr adiabatic oxygen bomb calorimeter KL-10 (Precyzja, Bydgoszcz, Poland). Faecal N in excreta was determined according to Ekman et al. (1949).

\section{Histological examinations}

Segments of small intestines were fixed in Bouins solution for 5 days, then dehydrated and embedded in paraffin. Serial histological sections of $5 \mu \mathrm{m}$ thickness 
were cut from the waxed tissues on a microtome and mounted on slides. The slides were stained with haematoxylin, counter-stained with eosin and examined under a light microscope (Nikon Corp., Yokohama, Japan), coupled with a camera (Panasonic KR222, Matsushita E.I.Co. Osaka, Japan) to a computer. Villus height (from tip to crypt mouth), villus width (in the middle of its length), crypt depth (from crypt mouth to base) and width of the tunica muscularis and submucosa were measured. Measurements of villus height and crypt depth were taken only from sections where the section plane ran vertically from the tip of the villus to the base of an adjacent crypt. Averages represent at least 6 slides, in each slide 30 well-oriented villi and crypts were measured using Lucia G v 4.60 software (Laboratory Imaging Ltd., Prague, Czech Republic).

\section{Calculations and statistical analysis}

BWG and FCR were calculated for the period of 2 weeks (8-21d). Apparent digestibility of protein, fat and organic matter, as well as nitrogen retention and apparent metabolizable energy value of diets were calculated relative to the ratio of $\mathrm{Cr}_{2} \mathrm{O}_{3}$ in feed and droppings according to Hill and Anderson (1958). Metabolizable energy $\left(\mathrm{AME}_{\mathrm{N}}\right.$ ) was corrected to zero nitrogen balance using $34.39 \mathrm{~kJ} / \mathrm{g} \mathrm{N}$ retained. The weight of organs was calculated relative to live body weight before slaughter. Means and pooled standard errors of means were calculated by standard procedures. The results were subjected to statistical analysis using one-way analysis of variance and significance of feed enzyme effect was analysed by the Tukey HSD test. The significance of organic acid preparation effect and interaction with feed enzyme was analysed by two-way analysis of variance and the LSD test, with the use Statgraphics ${ }^{\circledR}$ ver. 5.1 (1994-2001).

\section{RESULTS}

Six chicks died during the first week of the experiment due to not absorbed yolk sac. In $8 \mathrm{~d}$ old chickens no significant effect of the feed additives on BWG or liver weight was observed, only the caecum weight with contents was significantly increased $(\mathrm{P}<0.05)$ in birds fed the diet containing preparation $\mathrm{G}$ and feed enzyme (Table 2). Feed additives affected small intestinal morphology in the jejunum - the diet with preparation $\mathrm{G}$ increased the villi height $(\mathrm{P}<0.001)$, crypt depth $(\mathrm{P}<0.01)$ and tunica muscularis width $(\mathrm{P}<0.05)$. Enzyme addition decreased the width of villi $(\mathrm{P}<0.05)$, while none of the additives had significant effects in the ileum (Table 2). 
Table 2. Effect of dietary treatments on relative weight of liver and caecum with contents and on morphological characteristics of jejunum and ileum in 8-d-old chickens, $n=8$

\begin{tabular}{|c|c|c|c|c|c|c|c|c|c|c|}
\hline \multirow[b]{2}{*}{ Item } & \multirow[b]{2}{*}{$\begin{array}{c}\text { Liver } \\
\% \\
\text { LBW }^{2}\end{array}$} & \multirow[b]{2}{*}{$\begin{array}{l}\text { Caecum } \\
\% \text { LBW }^{2}\end{array}$} & \multicolumn{4}{|c|}{ Jejunum } & \multicolumn{4}{|c|}{ Ileum } \\
\hline & & & $\begin{array}{c}\text { villus } \\
\text { height } \\
\mu \mathrm{m}\end{array}$ & $\begin{array}{l}\text { villus } \\
\text { width } \\
\mu \mathrm{m}\end{array}$ & $\begin{array}{c}\text { crypt } \\
\text { depth } \\
\mu \mathrm{m}\end{array}$ & $\begin{array}{c}\text { tunica } \\
\text { muscularis } \\
\text { width, } \mu \mathrm{m}\end{array}$ & $\begin{array}{c}\text { villus } \\
\text { height } \\
\mu \mathrm{m} \\
\end{array}$ & $\begin{array}{l}\text { villus } \\
\text { width } \\
\mu \mathrm{m}\end{array}$ & $\begin{array}{c}\text { crypt } \\
\text { depth } \\
\mu \mathrm{m}\end{array}$ & $\begin{array}{c}\text { tunica } \\
\text { muscularis } \\
\text { width, } \mu \mathrm{m}\end{array}$ \\
\hline \multicolumn{11}{|c|}{$\overline{\text { Dietary treatments }}^{I}$} \\
\hline $\mathrm{B}$ & 4.92 & 0.94 & $668^{\mathrm{a}}$ & $140^{\mathrm{c}}$ & $166^{\mathrm{a}}$ & $100^{\mathrm{a}}$ & 648 & 138 & 166 & 147 \\
\hline $\mathrm{BE}$ & 5.23 & 1.11 & $674^{\mathrm{a}}$ & $101^{\mathrm{a}}$ & $154^{\mathrm{a}}$ & $101^{\mathrm{a}}$ & 560 & 127 & 158 & 138 \\
\hline BG & 5.19 & 1.14 & $873^{\mathrm{b}}$ & $144^{\mathrm{c}}$ & $192^{\mathrm{b}}$ & $112^{\mathrm{ab}}$ & 528 & 110 & 142 & 133 \\
\hline BEG & 5.28 & 1.30 & $896^{\mathrm{b}}$ & $134^{\mathrm{bc}}$ & $203^{\mathrm{b}}$ & $129^{b}$ & 643 & 152 & 165 & 147 \\
\hline BSB & 5.31 & 1.18 & $695^{\mathrm{a}}$ & $118^{\mathrm{abc}}$ & $152^{\mathrm{a}}$ & $91^{\mathrm{a}}$ & 653 & 140 & 156 & 140 \\
\hline BESB & 5.15 & 1.11 & $695^{\mathrm{a}}$ & $110^{\mathrm{ab}}$ & $149^{\mathrm{a}}$ & $92^{\mathrm{a}}$ & 532 & 129 & 144 & 146 \\
\hline $\begin{array}{r}\text { Pooled } \\
\text { SEM }\end{array}$ & 0.13 & 0.06 & 37 & 10 & 8.8 & 7.4 & 25 & 5.9 & 7.1 & 8.5 \\
\hline \multicolumn{11}{|c|}{ Main effects } \\
\hline G & ns & $* *$ & $* * *$ & ns & $* *$ & $*$ & ns & ns & ns & ns \\
\hline SB & ns & ns & ns & ns & ns & ns & ns & ns & ns & ns \\
\hline enzyme & ns & ns & ns & * & ns & ns & ns & ns & ns & ns \\
\hline
\end{tabular}

${ }^{1}$ as in Table $1 ;{ }^{2}$ live body weight; $;{ }^{\text {a,b }}$ means in a column with different superscripts differed significantly at $\mathrm{P}<0.05 ; * \mathrm{P}<0.05 ; * * \mathrm{P}<0.01 ; * * * \mathrm{P}<0.001$; all interactions insignificant

During the growth experiment (8-21d), one bird died with symptoms of ascites and 7 chickens were rejected from the final calculations (after slaughter inspection yielded 2 birds as males, 5 birds had a distended crop and/or gizzard). BWG in groups fed enzyme-supplemented diets was improved due to higher feed intake, while SB positively $(\mathrm{P}<0.05)$ affected feed conversion ratio in comparison with the control diet (Table 3).

The results of the balance trial are shown in Table 4. The supplementation of feed enzyme did not affect nitrogen digestibility in comparison with the control diet, while nitrogen retention increased due to supplementation of preparation $\mathrm{G}(\mathrm{P}<0.01)$ and $\mathrm{SB}(\mathrm{P}<0.001)$. Organic matter digestibility and $\mathrm{AME}_{\mathrm{N}}$ value increased significantly following enzyme supplementation $(\mathrm{P}<0.01)$ in comparison with the control group, while preparation SB improved $(\mathrm{P}<0.05)$ only organic matter digestibility. The increase in organic matter digestibility and $\mathrm{AME}_{\mathrm{N}}$ due to feed enzyme supplementation was more pronounced when the basal diet contained no organic acid preparations. The interactions between feed enzyme and organic acid effect were significant $(\mathrm{P}<0.01)$. Crude fat digestibility was not affected by treatments (Table 4). 
Table 3. Performance of broilers, 8-21 day of life

\begin{tabular}{|c|c|c|c|c|c|c|}
\hline Item & $\begin{array}{c}\text { Initial } \\
\mathrm{n}\end{array}$ & $\begin{array}{c}\text { Initial body } \\
\text { weight, } g\end{array}$ & $\begin{array}{c}\text { Final } \\
\mathrm{n}\end{array}$ & $\begin{array}{c}\mathrm{BWG}^{2} \\
\mathrm{~g}\end{array}$ & $\begin{array}{c}\text { Feed intake } \\
\mathrm{g}\end{array}$ & $\begin{array}{c}\mathrm{FCR}^{3}, \mathrm{~g} \\
\text { feed/g BWG }\end{array}$ \\
\hline \multicolumn{7}{|c|}{ Dietary treatments ${ }^{l}$} \\
\hline B & 16 & 173 & 16 & $734^{\mathrm{a}}$ & $1043^{\mathrm{bc}}$ & $1.42^{\mathrm{a}}$ \\
\hline $\mathrm{BE}$ & 16 & 172 & 14 & $746^{\mathrm{a}}$ & $1053^{\mathrm{bc}}$ & $1.41^{\mathrm{ab}}$ \\
\hline BG & 16 & 176 & 14 & $704^{a}$ & $997^{\mathrm{ab}}$ & $1.42^{\mathrm{ab}}$ \\
\hline BEG & 16 & 174 & 14 & $737^{\mathrm{a}}$ & $1016^{\mathrm{abc}}$ & $1.38^{\mathrm{ab}}$ \\
\hline BSB & 16 & 175 & 16 & $721^{\mathrm{ab}}$ & $982^{\mathrm{a}}$ & $1.36^{\mathrm{ab}}$ \\
\hline BESB & 16 & 172 & 14 & $792^{\mathrm{b}}$ & $1066^{\mathrm{c}}$ & $1.35^{\mathrm{b}}$ \\
\hline Pooled SEM & & 2.3 & & 16.2 & 22.2 & 0.02 \\
\hline \multicolumn{7}{|l|}{ Main effects } \\
\hline G & & ns & & ns & ns & ns \\
\hline SB & & ns & & ns & ns & $*$ \\
\hline enzyme & & ns & & $* *$ & $*$ & ns \\
\hline
\end{tabular}

Table 4. The nitrogen retention and digestibility of nutrients (in \% of intake) and metabolizable energy value of experimental diets ( 22 to 26 day of age), $n=9$

\begin{tabular}{|c|c|c|c|c|c|}
\hline \multirow[b]{2}{*}{ Item } & \multirow[b]{2}{*}{$\begin{array}{l}\text { Nitrogen } \\
\text { retention }\end{array}$} & \multicolumn{3}{|c|}{ Apparent total tract digestibility } & \multirow{2}{*}{$\begin{array}{c}\mathrm{AME}_{\mathrm{N}} \\
\mathrm{MJ} / \mathrm{kg} \mathrm{DM}^{3}\end{array}$} \\
\hline & & nitrogen & $\begin{array}{c}\text { organic } \\
\text { matter }^{2}\end{array}$ & crude fat & \\
\hline \multicolumn{6}{|c|}{$\overline{\text { Dietary treatments }}{ }^{I}$} \\
\hline B & $44.7^{\mathrm{a}}$ & $86.0^{\mathrm{ab}}$ & $68.1^{\mathrm{a}}$ & 88.4 & $14.5^{\mathrm{a}}$ \\
\hline $\mathrm{BE}$ & $45.2^{\mathrm{ab}}$ & $86.0^{\mathrm{ab}}$ & $70.5^{\mathrm{b}}$ & 89.9 & $15.2^{\mathrm{c}}$ \\
\hline BG & $49.6^{\mathrm{b}}$ & $86.1^{\mathrm{ab}}$ & $69.5^{\mathrm{ab}}$ & 88.9 & $14.9^{\mathrm{bc}}$ \\
\hline BEG & $47.5^{\mathrm{ab}}$ & $85.5^{\mathrm{a}}$ & $70.5^{\mathrm{b}}$ & 89.0 & $15.0^{\mathrm{bc}}$ \\
\hline BSB & $49.2^{\mathrm{ab}}$ & $86.6^{\mathrm{ab}}$ & $70.2^{\mathrm{b}}$ & 89.1 & $14.8^{\mathrm{ab}}$ \\
\hline BESB & $49.6^{b}$ & $87.0^{\mathrm{b}}$ & $70.4^{\mathrm{b}}$ & 89.3 & $15.0^{\mathrm{bc}}$ \\
\hline Pooled SEM & 1.09 & 0.34 & 0.50 & 0.45 & 0.09 \\
\hline \multicolumn{6}{|l|}{ Main effects } \\
\hline G & $* *$ & ns & ns & ns & ns \\
\hline SB & $* * *$ & $* *$ & $*$ & ns & ns \\
\hline enzyme $(E)$ & ns & ns & $* *$ & ns & $* * *$ \\
\hline
\end{tabular}

The weight of liver and caecum with contents in 4-week-old chickens as well as the results of digesta analysis are shown in Tables 5 and 6. Dietary treatments did not affect relative caecum weight, but liver weight was slightly increased in chickens fed diets with preparation G, in comparison with preparation SB. Dietary treatments did not affect the weight of the spleen or bursa of Fabricius (data not 
shown). The dry matter content of caecal digesta did not differ due to treatments, while the DM of ileal digesta was lower in groups fed diets with preparation SB. The effect of feed additives on the $\mathrm{pH}$ of crop and stomach contents was not significant, the added feed enzyme decreased the $\mathrm{pH}$ of jejunal digesta and preparation $\mathrm{G}$ decreased the $\mathrm{pH}$ of caecal digesta $(\mathrm{P}<0.05)$. Ileal digesta viscosity in birds fed diets without enzyme was $2.18 \mathrm{mPas} s$, on average, and decreased by

Table 5. The liver and caecum weight ( $\mathrm{n}=14$ or 16$)$, dry matter in ileal and caecal digesta, $\mathrm{pH}$ of gastrointestinal contents and viscosity of ileal digesta in mPass (29-30 day of age), $n=7$

\begin{tabular}{|c|c|c|c|c|c|c|c|c|c|}
\hline \multirow{2}{*}{ Item } & \multirow{2}{*}{$\begin{array}{c}\text { Liver } \\
\% \text { LBW }^{2}\end{array}$} & \multirow{2}{*}{$\begin{array}{l}\text { Caecum } \\
\% \text { LBW }^{2}\end{array}$} & \multicolumn{2}{|c|}{ DM of digesta, $\%$} & \multicolumn{4}{|c|}{$\mathrm{pH}$ of digesta } & \multirow{2}{*}{$\begin{array}{l}\text { Viscosity of } \\
\text { ileal digesta }\end{array}$} \\
\hline & & & ileum & caecum & crop & stomach & ileum & caecum & \\
\hline \multicolumn{10}{|c|}{ Dietary treatments $^{l}$} \\
\hline $\mathrm{B}$ & 2.74 & 0.43 & 17.5 & 18.2 & 5.21 & 4.36 & 6.32 & 6.54 & 2.13 \\
\hline $\mathrm{BE}$ & 2.96 & 0.60 & 17.8 & 22.2 & 4.97 & 4.06 & 6.20 & 6.65 & 1.96 \\
\hline BG & 3.16 & 0.44 & 17.0 & 20.4 & 4.89 & 4.22 & 6.74 & 6.23 & 2.27 \\
\hline BEG & 2.85 & 0.59 & 16.9 & 21.2 & 4.93 & 4.21 & 6.28 & 5.90 & 1.93 \\
\hline BSB & 2.72 & 0.55 & 16.8 & 20.5 & 4.96 & 4.27 & 6.28 & 6.21 & 2.13 \\
\hline BESB & 2.78 & 0.58 & 15.8 & 19.0 & 4.86 & 4.01 & 6.14 & 6.56 & 2.01 \\
\hline \multicolumn{10}{|l|}{ Pooled } \\
\hline SEM & 0.11 & 0.09 & 0.58 & 2.05 & 0.17 & 0.17 & 0.08 & 0.20 & 0.11 \\
\hline \multicolumn{10}{|l|}{ Main effects } \\
\hline G & $\mathrm{ns}$ & ns & ns & $\mathrm{ns}$ & ns & ns & ns & $*$ & ns \\
\hline SB & ns & $\mathrm{ns}$ & $*$ & $\mathrm{~ns}$ & $\mathrm{~ns}$ & $\mathrm{~ns}$ & $\mathrm{~ns}$ & ns & ns \\
\hline enzyme & ns & ns & ns & ns & ns & ns & $*$ & ns & $*$ \\
\hline
\end{tabular}

${ }^{1}$ as in Table $1 ;{ }^{2}$ live body weight; $* \mathrm{P}<0.05$; all interactions insignificant

Table 6. Effect of dietary treatments on concentrations of short-chain fatty acids (SCFA) in caecal digesta $(\mu \mathrm{M} / \mathrm{g}$ digesta $)$ in broilers at 29-30 day of age, $n=7$

\begin{tabular}{lccccccc}
\hline Item & $\begin{array}{c}\text { Total } \\
\text { SCFA }\end{array}$ & Acetate & Propionate & Butyrate & Isobutyrate & Valerate & Isovalerate \\
\hline \multicolumn{2}{l}{ Dietary treatments ${ }^{l}$} & & & & & & \\
B & 116.6 & 71.8 & 0.51 & 41.3 & 0.97 & 0.92 & 1.08 \\
BE & 112.6 & 70.1 & 0.75 & 37.7 & 1.33 & 1.44 & 1.44 \\
BG & 108.2 & 68.7 & 0.42 & 36.4 & 0.94 & 0.90 & 0.90 \\
BEG & 101.9 & 63.3 & 0.38 & 36.4 & 0.73 & 0.65 & 0.65 \\
BSB & 110.2 & 69.9 & 0.64 & 36.3 & 1.15 & 1.14 & 1.14 \\
BESB & 100.0 & 65.7 & 0.56 & 30.8 & 0.97 & 0.96 & 0.96 \\
Pooled & & & & & & & \\
$\quad$ SEM & 9.76 & 6.58 & 0.12 & 3.69 & 0.16 & 0.16 & 0.20 \\
Main effects & & & & & & & \\
G & $\mathrm{ns}$ & $\mathrm{ns}$ & $\mathrm{ns}$ & $\mathrm{ns}$ & $\mathrm{ns}$ & $*$ & $*$ \\
SB & $\mathrm{ns}$ & $\mathrm{ns}$ & $\mathrm{ns}$ & $\mathrm{ns}$ & $\mathrm{ns}$ & $\mathrm{ns}$ & $\mathrm{ns}$ \\
enzyme & $\mathrm{ns}$ & $\mathrm{ns}$ & $\mathrm{ns}$ & $\mathrm{ns}$ & $\mathrm{ns}$ & $\mathrm{ns}$ & $\mathrm{ns}$ \\
\hline
\end{tabular}

${ }^{1}$ as in Table $1 ; * \mathrm{P}<0.05$; all interactions insignificant 
$10 \%(\mathrm{P}<0.05)$ after enzyme supplementation, while both organic acid preparations did not affect this parameter. None of the additives affected total SCFA or acetic acid, butyric acid and isobutyric acid concentrations in caecal digesta. However, the concentrations of valeric and isovaleric acids were significantly lower in chickens fed the diets with preparation $\mathrm{G}$ than in birds fed control diet $(\mathrm{P}<0.05)$.

\section{DISCUSSION}

The contents of short-chain carboxylic acids in the gastrointestinal tract of nonruminants reflect the amount consumed and the rate of intraluminal production by anaerobic microorganisms from fermentable substrate. These acids have a number of important regulatory functions (via neural or humoral pathways) related to gastrointestinal functionality, among others mucosal development, proliferation, differentiation, maturation and apoptosis of enterocytes and colonocytes (Mroz et al., 2006). The bacterial counts and fermentation efficacy are very low in first week of a chicken's life (van der Wielen et al., 2000), so it may be hypothesized that the increase in luminal SCFA concentration can be essential for accelerated development of distal parts of the gastrointestinal tract. This hypothesis was partially confirmed in the present study by the increase of absorptive area (the increase of villus height and width), as well as the increase of crypt depth and tunica muscularis width in the jejunum of 8-day-old chickens provided the diet with the microencapsulated preparation composed of fumaric acid, calcium formate, calcium propionate and potassium sorbite. This may indicate that the preparation reached the small intestine, but probably the active components were released and absorbed in the fore part, as no effect in the ileum was found. Generally, butyrate is recognized as the most effective source of energy for epithelial cells proliferation (Mroz et al., 2006), but sodium butyrate in the current study had no positive effect on the development of the small intestinal epithelium. In conventional, healthy pigs and chickens the effect of sodium butyrate on small intestinal epithelium is often insignificant (Biagi et al., 2007; Hu and Guo, 2007), or targeted to the medium jejunum (Claus et al., 2007), but sodium butyrate has been reported to be helpful in maintenance of intestinal villi structure after coccidial challenge (Leeson et al., 2005).

In the current study, both organic acid preparations increased nitrogen retention in comparison with unsupplemented control diet, while BWG was not affected. The increase in nitrogen retention can be connected with greater epithelial cell proliferation in gastrointestinal tract. Hu and Guo (2007) reported that in broilers, sodium butyrate did not affect BWG, while increasing the protein concentration in duodenal mucosa. Also Hume et al. (1993) and Leeson et al. (2005) did not find 
any effect of added organic acids on the performance of chickens. In the present study, however, the performance of chickens fed diet supplemented simultaneously with both SB and feed enzyme was significantly better than in the group fed the unsupplemented basal diet.

In the present study, wheat constituted nearly $30 \%$ and maize $20 \%$ of experimental diets. The reduction of the viscosity of ileal digesta following enzyme supplementation indicated breaking down of viscous arabinoxylans and $\beta$-glucans of wheat by added xylanase and $\beta$-glucanase. The increased organic matter digestibility and $\mathrm{AME}_{\mathrm{N}}$ value of the diet and positive effect on body weight gain after enzyme supplementation are in general agreement with the mode of action of enzyme preparations (Bedford, 2000). However, the $\mathrm{pH}$ of ileal contents in enzyme-supplemented groups was lowered, indicating the increase of ileal microflora activity, while the $\mathrm{pH}$ of caecal contents as well as caecal SCFA concentration was not affected by enzyme supplementation. It is probable that in the present study the products of partial degradation of wheat and maize cell walls by added enzymes provided a fermentation substrate for specific bacteria in the ileum rather than in the caeca. Bedford (2000) supposed that in the absence of antibiotic growth promoters, enzyme supplementation would result in an increase of caecal microflora populations because the sugars provided by enzymatic action would be available to unrestrained caecal flora populations. The results of the present study did not confirm this supposition.

Although the organic acid blends are supposed to be a substitute for antibiotic growth promoters, it seems that they benefit the chickens in a different way. Bedford (2000) reported that in several experiments, antibiotic growth promoters more effectively improved FCR in chickens than feed enzymes, but the combination of both was even more effective. In the present study, the feed enzyme did not affect FCR but improved feed intake and BWG, which was depressed following both organic acid blends alone.

The results of the study indicate that encapsulated organic acids did not substantially change microflora activity in the distal parts of gastrointestinal tract, but their application in combination with feed enzymes may have positive effects throughout the broiler growth period.

\section{REFERENCES}

AOAC, 1990. Association of Official Analytical Chemists, Official Methods of Analysis. 15 $5^{\text {th }}$ Edition. Washington, DC

Bedford M., 2000. Removal of antibiotic growth promoters from poultry diets: implications and strategies to minimize subsequent problems. World Poultry Sci. J. 56, 347-365 
Biagi G., Piva A., Moschini M., Vezzali E., Roth F.X., 2007. Performance, intestinal microflora, and wall morphology of weanling pigs fed sodium butyrate. J. Anim. Sci. 85, 1184-1191

Bolton W., Dewar W.A., 1965. The digestibility of acetic, propionic and butyric acids by the fowl. Brit. Poultry Sci. 6, 103-105

Claus R., Günther D., Letzguss H., 2007. Effects of feeding fat-coated butyrate on mucosal morphology and function in the small intestine of the pig. J. Anim. Physiol. Anim. Nutr. 91, 312-318

Corrier D.E.A., Nisbet D.J., Scanlan C.M., Hollister A.G., DeLoach J.R., 1995. Control of Salmonella typhimurium colonization in broiler chicks with a continuous-flow characterized mixed culture of caecal bacteria. Poultry Sci. 74, 916-924

Ekman P., Emanuelson H., Fransson A., 1949. The digestibility of protein in poultry. Kungl. Lantbruks.-Hogskol. Ann. 16, 749

Hill F.W., Anderson D.L., 1958. Comparison of metabolizable energy and productive energy determinations with growing chicks. J. Nutr. 64, 587-603

Hinsberg K., Cremer H.D., Schmidt G., 1953. In: Hoppe-Seyler/Tierfelder-Handbuch der Physiologisch-und Patologisch-Chemischen Analyse, Vol. 5. Springer-Verlag, Berlin, pp. 402403

Hu Z., Guo Y., 2007. Effects of dietary sodium butyrate supplementation on the intestinal morphological structure, absorptive function and gut flora in chickens. Anim. Feed Sci. Tech. 132, 240-249

Hume M.E., Corrier D.E., Ivie G.W., Deloach J.R., 1993. Metabolism of $\left[{ }^{14}\right.$ C]propionic acid in broiler chicks. Poultry Sci. 72, 786-793

Leeson S., Namkung H., Antongiovanni M., Lee E.H., 2005. Effect of butyric acid on the performance and carcass yield of broiler chickens. Poultry Sci. 84, 1418-1422

Mroz Z., Koopmans S.-J., Bannink A., Partanen K., Krasucki W., Øverland M., Radcliffe S., 2006. Carboxylic acids as bioregulators and gut growth promoters in nonruminants. In: R. Mosenthin, J. Zentek, T. Żebrowska (Editors). Biology of Nutrition in Growing Animals. Elsevier, Edinburgh (UK), pp. 81-133

Smulikowska S., Rutkowski A. (Editors), 2005. Recommended Allowances and Nutritive Value of Feedstuffs - Poultry Feeding Standards (in Polish). $4^{\text {th }}$ Edition. The Kielanowski Institute of Animal Physiology and Nutrition, PAS, Jabłonna (Poland)

Statgraphics Plus ${ }^{\circledR}$ ver. 5.1, 1994-2001. Statistical Graphic System by Statistical Graphic Corporation, Manugistics, Inc. Rockville, MD (USA)

van der Wielen P.W.J.J., Biesterveld S., Notermans S., Hofstra H., Urlings A.P., van Knapen F., 2000. Role of volatile fatty acids in development of the cecal microflora in broiler chickens during growth. Appl. Environ. Microbiol. 66, 2536-2540

Ziołecki A., Kwiatkowska E., 1973. Gas chromatography of $\mathrm{C}_{1}$ to $\mathrm{C}_{5}$ fatty acids in rumen fluid and fermentation media. J. Chromatogr. 80, 250-254 